\title{
Pengaruh Model Search Solve Create Share (SSCS) Terhadap Kemampuan Pemahaman Konsep Matematis
}

\author{
Tristi Ardita Rismayanti ${ }^{1}$ \& Heni Pujiastuti ${ }^{2}$ \\ 1,2 Universitas Sultan Ageng Tirtayasa
}

\section{INFO ARTICLES}

Article History:

Received: 22-04-2020

Revised: 26-05-2020

Approved: 07-06-2020

Publish Online: 15-06-2020

\section{Key Words:}

Model Search Solve Create Share, Kemampuan Pemahaman Konsep Matematis

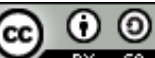
under a Creative Commons AttributionShareAlike 4.0 International License.

\begin{abstract}
Indonesian students are still classified as low in solving PISA problems, one of the reasons is the low understanding of students' mathematical concepts. The purpose of this study was to determine the effect of the Search Solve Create Share (SSCS) model on the ability to understand mathematical concepts compared to conventional learning with the lecture method. The study was conducted in SMP Negeri 1 Kramatwatu Serang VII class consisting of 46 students. The sampling technique in this study is Cluster Random Sampling. The method in this study is quasi-experimental. Normality test is done before hypothesis test. Then a non-parametric statistical test with the Mann-Whitney Test. Hypothesis testing results obtained significance $<0.05$ which shows that there are significant differences in the ability to understand mathematical concepts given the SSCS model rather than conventional learning with the lecture method. In this case, it means that there is an influence of the model SSCS on the ability to understand students' mathematical concepts.
\end{abstract}

Abstrak: Siswa Indonesia masih tergolong rendah dalam menyelesaikan soal PISA salah satu penyebabnya adalah rendahnya pemahaman konsep matematis siswa. Tujuan penelitian ini adalah untuk mengetahui pengaruh model Search Solve Create Share (SSCS) terhadap kemampuan pemahaman konsep matematis dibandingkan pembelajaran konvensional dengan metode ceramah. Penelitian dilakukan di SMP Negeri 1 Kramatwatu Serang kelas VII sebanyak 46 siswa. Teknik pengambilan sampel pada penelitian ini adalah Cluster Random Sampling. Metode pada penelitian ini adalah kuasi eksperimen. Uji normalitas dilakukan sebelum uji hipotesis penelitian. Kemudian dilakukan uji statistik non-parametrik dengan Mann-Whitney Test. Hasil pengujian hipotesis diperoleh signifikansi $<0.05$ yang menunjukkan bahwa terdapat perbedaan yang signifikan pada kemampuan pemahaman konsep matematis yang diberikan model SSCS daripada pembelajaran konvensional dengan metode ceramah. Dalam hal ini berarti terdapat pengaruh model SSCS terhadap kemampuan pemahaman konsep matematis siswa.

Correspondence Address: Jln. Widelia IX Blok AI1E17 No. 6 RT 05/03 PWS Tigaraksa, Kab. Tangerang, Banten, 15720, Indonesia; e-mail: tristiarditary@gmail.com

How to Cite (APA $6^{\text {th }}$ Style): Rismayanti, T. A. \& Pujiastuti, H. (2020). Pengaruh Model Search Solve Create Share (SSCS) Terhadap Pemahaman Konsep dan Pemecahan Masalah Matematika. JKPM (Jurnal Kajian Pendidikan Matematika), 5 (2): 183-190.

Copyright: Rismayanti, T. A. \& Pujiastuti, H. (2020)

Competing Interests Disclosures: The authors declare that they have no significant competing financial, professional or personal interests that might have influenced the performance or presentation of the work described in this manuscript. 


\section{PENDAHULUAN}

Rendahnya kemampuan pemahaman konsep matematis siswa Indonesia masih tergolong rendah. Hal tersebut didukung oleh penelitian Johar \& Zainabar (2013) hanya 15\% siswa yang berhasil memecahkan masalah matematika PISA pada konten space and shape. Rendahnya kemampuan siswa dalam memecahkan masalah matematika dapat disebabkan oleh rendahnya kemampuan pemahaman konsep matematis siswa. Keterkaitan antara pemahaman konsep dengan menyelesaikan soal pemecahan masalah dapat dilakukan dengan memberikan soal non-rutin, yang bertujuan agar siswa terbiasa memahami soal dan menggunakan konsep yang dimilikinya (Fatqurhohman, 2016). Faktor penyebab rendahnya pemahaman konsep matematis siswa yaitu guru kurang mengoptimalkan atau memberikan kesempatan kepada siswa untuk membangun sendiri konsep matematika (Ekaputri, 2016). Sama halnya seperti siswa SMP lainnya di Indonesia yang masih tergolong rendah kemampuan pemahaman konsepnya, siswa kelas VII pada SMP Negeri 1 Kramatwatu Serang juga masih tergolong rendah kemampuan pemahaman konsepnya berdasarkan observasi yang dilakukan peneliti. Kebanyakan siswa masih kurang memahami konsep dasar matematika. Hal tersebut dapat terjadi karena guru menyampaikan konsep matematika dengan metode konvensional, dimana guru belum melibatkan siswa dalam proses berpikir untuk menemukan konsep. Dalam proses pembelajaran matematika, guru belum berorientasi pada siswa, guru masih memberikan konsep matematika yang telah ada tanpa membangun stimulas pada siswa untuk dapat menemukan ide-ide dalam kegiatan penemuan konsep. Sehingga yang terjadi adalah siswa hanya dapat mengerjakan soal tanpa mengerti untuk apa soal tersebut dalam kehidupan sehari-hari. Siswa tidak dapat menggunakan konsep tersebut pada situasi yang berbeda karena terbiasa dengan menghapal rumus atau konsep (Novitasari, 2016). Pada akhirnya menimbulkan pola pikir yang terus berulang dimana banyak siswa didapati lebih mudah menyalin jawaban atau langkah pemecahan masalah tanpa proses analisis terlebih dahulu. Akibatnya terjadilah proses penghafalan konsep, pemahaman konsep matematika yang rendah, serta tidak dapat menggunakan konsep tersebut apabila diberikan permasalahan yang kompleks (Saragih, 2012). Peneliti juga melakukan wawancara dengan salah satu guru mata pelajaran matematika di SMP Negeri 1 Kramatwatu Serang, menurut beliau saat pembelajaran siswa masih kurang aktif ketika guru menyampaikan materi dengan metode ceramah. Akibat pembelajaran dengan metode ceramah yang lebih dominan berpusat pada guru menjadikan siswanya tidak terlibat dalam proses mengkonstruksikan pengetahuannya (Widyastuti, 2015). Sehingga kemampuan pemahaman konsep matematis dan kemampuan pemecahan masalah matematis yang di peroleh siswa masih rendah.

Beberapa penelitian sebelumnya mengenai model pembelajaran Search, Solve, Create, and Share (SSCS) telah dilakukan dan penelitian tersebut mampu meningkatkan kemampuan pemahaman konsep matematis siswa. Seperti penelitian yang dilakukan oleh Agustin, S. et al (2018: 52) terdapat perbedaan pemahaman konsep antara siswa yang mengikuti pembelajaran SSCS dengan siswa yang mengikuti pembelajaran konvensional tetapi tidak terdapat interaksi antara model pembelajaran SSCS yang ditinjau berdasarkan pengetahuan awal terhadap pemahaman konsep. Hal ini serupa dengan penelitian Astuti, N. P. E. F et al., (2018) yakni model Search, Solve, Create, and Share (SSCS) lebih baik dari pemahaman konsep matematika siswa yang mengikuti pembelajaran dengan pembelajaran konvensional. Haniyyah et al., (2020: 109) juga melakukan penelitian yang hasilnya terdapat peningkatan yang signifikan antara kemampuan pemahaman konsep matematis siswa yang belajar matematika menggunakan model pembelajaran SSCS namun disposisi matematis siswa yang belajar matematika menggunakan model pembelajaran SSCS mengalami peningkatan yang tidak signifikan.

Selama ini proses pembelajaran yang dilakukan di SMP Negeri 1 Kramatwatu Serang lebih dominan menggunakan model pembelajaran konvensional dengan metode ceramah. Pembelajaran dengan metode ini tidak memberi kesempatan siswa untuk mengeksplorasi materi secara mandiri dan kreatif. Dalam 
pembelajaran konvensional guru dalam menyampaikan materi lebih banyak dilakukan dengan ceramah, tanya jawab, dan penugasan (Rasana, 2009:20). Maka dari itu, perlu adanya model pembelajaran yang inovatif yang dapat meciptakan suasana baru sehingga siswa tidak bosan dan munculnya minat belajar matematika. Ada banyak model pembelajaran yang dapat diterapkan di sekolah, salah satunya model pembelajaran Search Solve Create Share (SSCS) yang digunakan dalam penelitian ini. The SSCS problem solving model is designed to expand and apply science concept and critical thinking skills (Pizzini, 1991:3). Model pembelajaran SSCS merupakan model pembelajaran yang dikembangkan oleh Pizzini yang dirancang untuk memengaruhi atau meningkatkan pemahaman konsep dan mengembangkan keterampilan berpikir kritis sehingga membantu siswa dalam memecahkan masalah matematika. Model pembelajaran SSCS merupakan suatu langkah pembelajaran yang memberikan kesempatan kepada siswa untuk terlibat aktif dalam proses pembelajaran karena keunggulan dari model SSCS ini adalah meningkatkan kemampuan bertanya, meningkatkan dan memperbaiki interaksi antar siswa, mengembangkan dan membuat siswa menjadi belajar bertanggung jawab terhadap pembelajaran yang mereka ikuti (Agustin, S., Fitraini, D., Rahmi \& Fitri, 2018). Sehingga model pembelajaran ini tidak hanya terpusat kepada guru tetapi siswa juga ikut serta dalam pembelajaran melalui proses bertanya hingga mempresentasikan hasil kerja mereka. Model pembelajaran SSCS ini memiliki 4 fase dalam proses pembelajaran, yaitu: fase search yang bertujuan untuk mengidentifikasi masalah. Kemudian, fase solve yang bertujuan untuk merencanakan penyelesaian masalah. Fase create bertujuan untuk melaksanakan penyelesaian masalah. Yang terakhir fase share yang bertujuan untuk mensosialisasikan penyelesaian masalah yang dilakukan (Haniyyah et al., 2020). Melalui ke empat fase model pembelajaran SSCS ini, diharapkan dapat membantu siswa dalam membentuk sebuah konsep matematis yang tepat sehingga siswa dapat lebih memahami konsep.

Berdasar pada deskripsi yang telah dipaparkan di atas, model pembelajaran Search Solve Create Share (SSCS) diduga mampu berpengaruh terhadap kemampuan pemahaman konsep matematis daripada pembelajaran konvensional dengan metode ceramah. Belum ada penelitian yang membahas mengenai pemahaman konsep matematis dengan model SSCS, yang mana arti kemampuan matematis adalah kemampuan untuk menghadapi masalah-masalah baik dalam permasalahan matematika maupun permasalahan dalam kehidupan nyata (Aledya, 2019). Sehingga pada penelitian ini siswa diharapkan tidak hanya pandai dalam memahami konsep dalam permasalahan matematika saja tetapi konsep matematika dapat digunakan dalam kehidupan nyata. Untuk itu peneliti ingin mengetahui apakah terdapat pengaruh model pembelajaran SSCS terhadap kemampuan pemahaman konsep matematis.

\section{METODE}

Penelitian ini dilaksanakan di SMP Negeri 1 Kramatwatu Serang pada pertengahan Februari 2020. Populasi penelitian ini adalah seluruh siswa kelas VII SMP Negeri 1 Kramatwatu Serang yang berjumlah 207 siswa. Sampel yang diambil secara acak yaitu kelas VIIE sebanyak 23 siswa dan kelas VIIF sebanyak 23 siswa.

Metode yang digunakan dalam penelitian ini adalah metode kuasi eksperimen. Pada kelas eksperimen diberikan tes awal untuk melihat kemampuan awal siswa, setelah itu penerapan model pembelajaran SSCS ketika proses pembelajaran. Setelah proses pembelajaran selesai, siswa diberikan tes akhir untuk melihat apakah terdapat perbedaan. Hal yang sama juga dilakukan pada kelas kontrol. Desain penelitian yang digunakan adalah desain pretes-postes control group design. 
Tabel 1. Desain Penelitian

\begin{tabular}{ccccc}
\hline Kelompok & & Pre-Test & Perlakuan & Post-Test \\
\hline K.Eksperimen (R) & $\mathrm{R}$ & $\mathrm{O}_{1}$ & $\mathrm{X}$ & $\mathrm{O}_{2}$ \\
K.Kontrol (R) & $\mathrm{R}$ & $\mathrm{O}_{3}$ & & $\mathrm{O}_{4}$ \\
\hline
\end{tabular}

Sumber: Sugiyono, 2012

Teknik pengambilan sampel menggunakan Cluster Random Sampling. Peneliti menggunakan teknik ini sebab populasi pada SMP Negeri 1 Kramatwatu Serang terdiri dari kelompok belajar yang terbagi dalam beberapa kelas. Instrumen yang digunakan berupa lembar tes uraian pretes postes untuk mengetahui kemampuan pemahaman konsep matematis materi Bentuk Aljabar berdasarkan instrumen yang telah tervalidasi dalam skripsi oleh Isnaina Faradisa yang berjudul Penerapan Model Pembelajaran Kooperatif Tipe Make A Match terhadap Pemahaman Konsep Matematis Siswa Kelas VIII SMPN 1 Simon Ponorogo yang diberikan sebelum pembelajaran dan setelah pembelajaran.

Sebelum melakukan uji hipotesis dilakukan prasyarat yaitu uji normalitas. Uji normalitas dilakukan dengan menggunakan Kolmogorov-Smirnov dan Shapiro-Wilk. Bila nilai signifikansi $>0,05$ maka distribusi data normal, sedangkan bila nilai signifikansi $<0,05$ maka distribusi dinyatakan tidak normal. Kemudian dilakukan uji statistik non parametrik dengan menggunakan uji Mann-Whitney.

\section{HASIL}

Perhitungan analisis deskriptif diperoleh dalam tabel berikut:

Tabel 2. Statistik Deskriptif

\begin{tabular}{lccccc}
\hline & N & Minimum & Maximum & Mean & $\begin{array}{c}\text { Std. } \\
\text { Deviation }\end{array}$ \\
\hline Pre-Test Eksperimen & 23 & 50 & 63 & 54.54 & 3.960 \\
Post-Test Eksperimen & 23 & 55 & 85 & 69.13 & 8.175 \\
Pre-Test Kontrol & 23 & 50 & 63 & 53.02 & 3.607 \\
Post-Test Kontrol & 23 & 50 & 73 & 61.74 & 7.592 \\
Valid N (listwise) & 23 & & & & \\
\hline
\end{tabular}

Sumber: Data Hasil Penelitian yang Dianalisis

Berdasar pada hasil yang diperoleh pada Tabel 2 diperoleh rata-rata skor kemampuan pemahaman konsep matematis siswa pada kelas kontrol naik sebanyak 8,72 dari 53,02 menjadi 61,74. Sedangkan ratarata skor kemampuan pemahaman konsep matematis siswa pada kelas eksperimen naik 14,59 dari 54,54 menjadi 69,13. Kemudian dilakukan uji normalitas data dengan menggunakan Kolmogorov-Smirnov dan Shapiro-Wilk yang dilakukan untuk mengetahui apakah sampel yang diteliti berasal dari populasi yang berdistribusi normal atau berdistribusi tidak normal. 
Tabel 3. Uji Normalitas

\begin{tabular}{llcccccc}
\hline $\begin{array}{l}\text { Pemahaman } \\
\text { Konsep } \\
\text { Matematika }\end{array}$ & \multicolumn{1}{c}{ Kelas } & \multicolumn{2}{c}{$\begin{array}{c}\text { Kolmogorov-Smirnov } \\
\text { Statistic }\end{array}$} & $\begin{array}{c}\text { Sf } \\
\text { Sig. }\end{array}$ & $\begin{array}{c}\text { Statistic } \\
\text { Shiro-Wilk }\end{array}$ & Sig. \\
\cline { 2 - 7 } & $\begin{array}{l}\text { Pre-Test } \\
\text { Eksperimen } \\
\text { (SSCS) }\end{array}$ & 0.221 & 23 & 0.005 & 0.878 & 23 & 0.009 \\
& $\begin{array}{l}\text { Post-Test } \\
\text { Eksperimen } \\
\text { (SSCS) }\end{array}$ & 0.242 & 23 & 0.001 & 0.874 & 23 & 0.008 \\
& $\begin{array}{l}\text { Pre-Test Kontrol } \\
\text { Konvensional) }\end{array}$ & 0.278 & 23 & 0.000 & 0.813 & 23 & 0.001 \\
& $\begin{array}{l}\text { Post-Test } \\
\text { Kontrol } \\
\text { Konvensional) }\end{array}$ & 0.211 & 23 & 0.009 & 0.900 & 23 & 0.025 \\
\hline
\end{tabular}

Sumber: Data Hasil Penelitian yang Dianalisis

Dari hasil uji normalitas yang dilakukan diatas dapat diketahui bahwa nilai signifikansi $<0,05$ yang berarti data berdistribusi tidak normal. Hasil pengujian normalitas diatas dapat kita lihat dari nilai Sig. keempat data yaitu $0.009,0.008,0.001$, dan 0.025 yang mana $<0.05$.

Dikarenakan terdapat data yang berdistribusi tidak normal maka dilakukan uji statistik non parametrik dengan menggunakan uji Mann-Whitney. Hipotesis penelitian untuk uji Mann-Whitney adalah terdapat pengaruh model pembelajaran SSCS terhadap kemampuan pemahaman konsep matematis. Adapun hasil uji Mann-Whitney sebagai berikut:

Tabel 4. Mann-Whitney

\begin{tabular}{lc}
\hline & Pemahaman Konsep Matematis \\
\hline Mann-Whitney $U$ & 137.000 \\
Wilcoxon $W$ & 413.000 \\
$Z$ & -2.848 \\
Asymp. Sig. (2-tailed) & 0.004 \\
\hline
\end{tabular}

Sumber: Data Hasil Penelitian yang Dianalisis

Hasil uji dengan Mann-Whitney Test menunjukkan bahwa nilai Asymp. Sig. (2-tailed) sebesar 0,004 $<0,005$. Maka dapat disimpulkan bahwa hipotesis diterima. Dengan demikian, dapat dikatakan bahwa terdapat pengaruh pada kemampuan pemahaman konsep matematis siswa yang di berikan model pembelajaran Search Solve Create Share (SSCS).

\section{PEMBAHASAN}

Berdasar pada hasil uji statistik non-parametrik dengan Mann-Whitney Test dapat disimpulkan bahwa terdapat perbedaan yang signifikan pada kemampuan pemahaman konsep matematis siswa yang diajarkan dengan model pembelajaran SSCS daripada siswa yang diberikan pembelajaran konvensional dengan metode ceramah. Hal tersebut terlihat dari perbedaan hasil post test siswa pada kemampuan pemahaman konsep dengan model pembelajaran SSCS. Jadi, dapat disimpulkan bahwa terdapat pengaruh model pembelajaran SSCS terhadap kemampuan pemahaman konsep matematis. 
Adanya pengaruh ini disebabkan karena adanya penerapan model pembelajaran SSCS yang mana langkah pembelajarannya menuntut siswa untuk ikut serta dalam pembelajaran khususnya dalam mengasah kemampuan pemahaman konsep matematis sehingga memudahkan siswa dalam memecahkan masalah matematika. Hal ini sejalan dengan pendapat Deli (2014: 72), "Model pembelajaran Search Solve Create Share (SSCS) adalah model pembelajaran yang melibatkan siswa dalam setiap tahapannya yaitu: tahap Search (tahap pencarian), tahap Solve (tahap pemecahan masalah), tahap Create (tahap menyimpulkan), dan tahap Share (tahap menampilkan)". Langkah pertama Search, siswa dibantu untuk mencari/menggali informasi seluas-luasnya tentang materi yang sedang dipelajari dapat melalui kehidupan nyata atau dengan pengalaman belajar seperti menyatakan ulang konsep, mengklasifikasikan objek, mengetahui sifat-sifat pokok bahasan, serta mengetahui contoh yang berkaitan dengan materi. Kemudian Solve, siswa dibantu untuk menemukan alternatif jawaban dari permasalahan serta menyajikan konsep dalam bentuk kalimat matematis yang terpenting pada fase ini adalah siswa harus mampu menentukan ide penyelesaian dari masalah yang diberikan. Create, siswa dituntun menuju suatu konsep matematis setelah dari kegiatan mencari dan menemukan alternatif jawaban seperti memilih operasi atau prosedur atau cara yang akan digunakan untuk menyelesaikan masalah, serta mulai mengaplikasikan konsep dengan permasalahan tersebut. Model pembelajaran terakhir adalah Share, membagikan segala informasi yang diterima siswa kepada siswa yang lainnya seperti mempresentasikan atau berdiskusi dengan teman sebayanya.

Kemampuan pemahaman konsep matematika adalah kemampuan siswa dalam menemukan dan menjelaskan, menerjemahkan, menafsirkan, dan menyimpulkan suatu konsep matematika berdasarkan pembentukan pengetahuannya sendiri, bukan sekedar menghapal (Pratiwi, 2016). Dengan model SSCS ini siswa benar-benar memahami bukan sekedar menghafal sehingga apabila siswa menghadapi soal atau memecahkan masalah yang berbeda dari contoh siswa tetap bisa mengerjakannya. Berbeda dengan pembelajaran konvensional dengan metode ceramah hanya dilakukan secara satu arah dimana siswa hanya menerima pengetahuan bukan membentuk pengetahuannya sendiri, akibatnya tidak terjadinya proses berpikir matematis untuk menemukan konsep. Hal ini dapat terlihat dari cara siswa memecahkan suatu masalah, apabila diberikan masalah yang berbeda atau lebih kompleks siswa akan mengalami kesulitan. Sebagai contohnya saja ketika siswa diberikan permasalahan matematika yang berhubungan dengan kehidupan sehari-hari akan merasa kesulitan. Padahal ilmu matematika yang akan memudahkan siswa dalam kehidupan sehari-hari maupun disiplin ilmu lainnya. Model pembelajaran SSCS dapat digunakan untuk memudahkan proses pembelajaran dikelas karena melibatkan guru dan siswa secara aktif sehingga yang diharapkan proses pembelajaran dikelas dapat membekas diingatan siswa sehingga ilmu matematika dapat digunakan untuk memecahkan berbagai masalah dalam kehidupan sehari-hari.

Teori yang mendasari model pembelajaran SSCS adalah teori konstruktivisme Piaget yang menjelaskan bahwa proses dibangunnya sebuah pengetahuan dari stimulus baru dilakukan dengan dua cara, yaitu asimilasi dan akomodasi (Suherman, 2003). Proses asimilasi dan akomodasi ini akan terbentuk tentunya melalui bantuin guru sebagai mediator dan fasilitator yang membantu siswa mencapai stimulus barunya, sehingga peran guru pada model pembelajaran ini juga sangat penting. Model pembelajaran SSCS ini akan membentuk siswa menjadi pribadi yang aktif dan kritis maka tidak hanya siswa yang harus aktif serta kritis tetapi guru pun harus aktif dan kritis dalam melakukan proses pembelajaran di kelas. Model pembelajaran SSCS sangat cocok untuk membangun stimulus baru supaya siswa lebih mudah memahami konsep dan tidak sekedar menghafal tetapi juga paham sehingga apabila diberikan permasalahan yang lebih kompleks siswa tetap bisa menyelesaikan masalah tersebut.

Adapun kendala dalam melakukan penelitian ini yaitu, siswa masih kurang berpartisipasi aktif dalam proses pembelajaran. Dalam melakukan kegiatan Share siswa masih malu/sungkan untuk menjelaskan hasil diskusi atau hasil berpikirnya kepada teman sebayanya. Hal yang harus dilakukan untuk mengatasi kendala ini adalah memberikan semangat atau motivasi kepada siswa ataupun memberikan reward atas keberanian 
atau kepercayaan diri mereka. Sebab keterlibatan aktif siswa di dalam kelas sangat menentukan sikap atau responnya dalam bermasyarakat, sehingga diharapkan guru mulai membiasakan siswa dari Taman Kanankanan untuk terlibat aktif dalam pembelajaran sehingga ketika ke jenjang sekolah yang lebih tinggi siswa telah terbiasa untuk berpartisipasi aktif dalam belajar.

Dengan pengalaman belajar yang demikian siswa menjadi lebih mudah memahami konsep, sebab mereka diarahkan untuk mencari informasi terlebih dahulu dan bukan sekedar menerima informasi yang akibatnya siswa hanya menghafal suatu konsep tetapi tidak memahami konsep itu sendiri. Oleh karena itu, penerapan model pembelajaran yang tepat pada situasi kelas tertentu sangat diperlukan untuk mendukung pembelajaran dalam upaya meningkatkan kualitas proses pembelajaran sehingga terbentuknya siswa yang memiliki kemampuan matematis yang baik.

\section{SIMPULAN}

Berdasar pada hasil penelitian dan pengujian hipotesis yang telah dipaparkan diatas, maka dapat disimpulkan bahwa model pembelajaran SSCS berpengaruh terhadap kemampuan pemahaman konsep matematis siswa di kelas VII SMP Negeri 1 Kramatwatu pada materi bentuk aljabar. Sebab model pembelajaran SSCS mampu membangun stimulus baru dimana siswa lebih mudah memahami konsep dan tidak sekedar menghafal tetapi juga paham sehingga apabila diberikan permasalahan yang lebih kompleks siswa tetap bisa memecahkan masalah tersebut. Dari hasil penelitian ini diharapkan model SSCS dapat digunakan oleh guru matematika sebagai referensi mengajar dikelas serta diharapkan dapat berkontribusi bagi guru dan peneliti lainnya untuk terus mengembangkan alternatif pembelajaran matematika.

\section{UCAPAN TERIMA KASIH}

Penulis ingin menyampaikan ucapan terima kasih kepada seluruh pihak yang membantu menyelesaikan artikel ini. Tentunya kepada Allah SWT yang memberikan kesehatan kepada penulis serta kedua orangtua penulis yang memberikan dukungan moril dan non moril. Kemudian kepala SMP Negeri 1 Kramatwatu Serang yang telah memberikan izin melalukan kegiatan penelitian. Serta ibu dan bapak guru matematika yang telah meluangkan sedikit waktu mengajarnya untuk penulis dan teman-teman siswa SMP Negeri 1 Kramatwatu Serang yang membantu kegiatan penelitian ini.

\section{DAFTAR RUJUKAN}

Agustin, S., Fitraini, D., Rahmi, D., \& Fitri, I. (2018). Pengaruh Model Pembelajaran Search Solve Create Share (SSCS) terhadap Pemahaman Konsep Matematis Ditinjau dari Pengetahuan Awal Siswa. Jurnal Pendidikan Matematika, 2(2), 43.

Aledya, Vivi. (2019). Kemampuan Pemahaman Konsep Matematika Pada Siswa. https://www.researchgate.net/publication/333293321_KEMAMPUAN_PEMAHAMAN_KONSEP_ MATEMATIKA_PADA_SISWA. Diakses dari laman web tanggal 26 Mei 2020.

Astuti, N. P. E. F., G. Suweken, \& D. Waluyo. (2018). Pengaruh Model Pembelajaran Search, Solve, Create And Share (SSCS) Terhadap Pemahaman Konsep Matematika Siswa Kelas VIII SMP Negeri 1 Banjar. Jurnal Pendidikan Matematika Undiksha, IX(2), 84-95. 
Deli, Maida. (2015). Penerapan Model Pembelajaran Search Solve Create Share (SSCS) untuk Meningkatkan Motivasi Belajar Matematika Siswa Kelas VII-2 SMP Negeri 13 Pekanbaru. Jurnal Primary Program Studi Pendidikan Guru Sekolah dasar Fakultas Keguruan dan Ilmu Pendidikan Universitas Riau, 4(1), 71-78.

Ekaputri, Y. N., (2016). Pengaruh Model Pembelajaran Generatif Terhadap Pemahaman Konsep Siswa Kelas VIII MTsN di Kabupaten Pesisir Selatan. Jurnal Pendidikan, 1(1), 57-64.

Fatqurhohman. (2016). Pemahaman Konsep Matematika Siswa dalam Menyelesaikan Masalah Bangun Datar. Jurnal Ilmiah Pendidikan Matematika, 4, 127-133.

Haniyyah, L., Iskandar, K., \& Rafianti, I. (2020). Pembelajaran Search, Solve, Create and Share (SSCS) untuk Meningkatkan Pemahaman Konsep dan Disposisi Matematis Siswa. Journal of Medives: Journal of Mathematics Education IKIP Veteran Semarang, 4(1), 97-110.

Johar, R., \& Zainabar. (2013). Student's Performance On Shape and Space Task of PISA Question. Proceeding International Conference On Education, 449-454.

Novitasari, D. (2016). Pengaruh Penggunaan Multimedia Interaktif Terhadap Kemampuan Pemahaman Konsep Matematis Siswa. FIBONACCI: Jurnal Pendidikan Matematika Dan Matematika, 2(2), 8. https://doi.org/10.24853/fbc.2.2.8-18.

Pizzini, Edward L. (1991). SSCS Implementation Handbook. Lowa: The University of Lowa.

Pratiwi, Dona, D. (2016). Pembelajaran Learning Cycle 5e Berbantuan Geogebra terhadap Kemampuan Pemahaman Konsep Matematis. Al-Jabar: Jurnal Pendidikan Matematika, 7(2), 191-202.

Rasana, I D. P. R. (2009). Model-model Pembelajaran. Singaraja: Universitas Pendidikan Indonesia.

Saragih, S. (2012). Menumbuhkembangkan Berpikir Logis dan Sikap Positif terhadap Matematika melalui Pendekatan Matematika Realistik. Malih Peddas (Majalah Ilmiah Pendidikan Dasar), 1(1). https://doi.org/10.26877/malihpeddas.v1i1.62.

Sugiyono. (2012). Metode Penelitian Kuantitatif Kualitatif dan R\&D. Bandung: Alfabeta.

Suherman, E. (2003). Strategi Pembelajaran Matematika Kontemporer. Bandung: JICA Press.

Widyastuti, Eri. (2015). Peningkatan Kemampuan Pemahaman Konsep dan Komunikasi Matematis Siswa Dengan Menggunakan Pembelajaran Kooperatif Tipe Jigsaw. Journal of Mathematics Education, 1(1), 1-14. https://doi.org/10.30595/alphamath.v1i1.208 